\title{
Embryo-initiated oviductal transport in mares
}

\author{
D. A. Freeman, G. L. Woods, D. K. Vanderwall and J. A. Weber \\ Northwest Equine Reproduction Laboratory, Department of Animal and Veterinary Science, \\ University of Idaho, Moscow, ID 83843, USA
}

\begin{abstract}
Summary. The hypothesis that equine embryos initiate oviductal transport in mares was tested by placing day 6 uterine embryos in the oviducts of day $2(n=10)$ or day $5(n=10)$ recipient mares and attempting to collect the embryos from the uterus $48 \mathrm{~h}$ later. To determine whether the surgical transfer procedure initiated oviductal transport, medium alone was placed in the oviducts of day $2(n=10)$ inseminated mares (sham transfer), and uterine embryo collections were attempted $48 \mathrm{~h}$ later.

Embryos were transported through the oviduct of day 2 recipients by day 4 (instead of day 5 to 6$)$ in six of ten mares, which was not significantly less $(P>0 \cdot 1)$ than in day 5 recipients $(9$ of 10 ). Oviductal transport was not primarily initiated by the surgical transfer procedure, since oviductal transport occurred in only one sham transfer.

There was no significant difference $(P>0 \cdot 1)$ in the diameter of embryos placed in the oviducts of day 2 and day 5 recipient mares (180 \pm 13.8 versus $187 \pm 11.3 \mu \mathrm{m}$, respectively). However, embryos collected from the uterus were significantly smaller $(P<0.05)$ in day 2 than in day 5 recipients $(375 \pm 85.4$ versus $659 \pm 43.6 \mu \mathrm{m}$, respectively). One uterine embryo had shed its zona pellucida before being placed in, and transported through, the oviduct of the recipient mare.
\end{abstract}

Keywords: horse; embryo; oviductal transport

\section{Introduction}

Most mammalian embryos and unfertilized oocytes enter the uterus at similar times after ovulation (Harper, 1988). However, in hamsters (Ortiz et al., 1986), rats (Villalon et al., 1982) and ferrets (Mead et al., 1988), embryos and unfertilized oocytes enter the uterus at different times after ovulation. In horses (Van Niekerk \& Gerneke, 1966; Steffenhagen et al., 1972; Betteridge \& Mitchell, 1974; Betteridge \& Mitchell, 1975; David, 1975; Onuma \& Ohnami, 1975; Flood et al., 1979) and long-tongued bats (Rasweiler, 1979) embryos enter the uterus but unfertilized oocytes are retained in the oviduct. Horse embryos therefore bypass unfertilized oocytes within the oviduct of the mare (Betteridge \& Mitchell, 1975; Onuma \& Ohnami, 1975). Retained, unfertilized oocytes apparently move distally in the oviducts (Steffenhagen et al., 1972) or occasionally enter the uterus (Wilson et al., 1985) with the passing embryos.

Most mammalian embryos enter the uterus 24-86 h after ovulation at the four- to 16-cell stage of development. Pig embryos enter the uterus at the four-cell stage $24-54 \mathrm{~h}$ after ovulation (Pomeroy, 1955; Oxenreider \& Day, 1965), cow embryos at the eight- to 16-cell stage 57-86 h after ovulation (Hamilton \& Laing, 1946; Crisman et al., 1980), and sheep embryos at the eight-cell stage 60-66 $\mathrm{h}$ after ovulation (Holst, 1974). In contrast, horse embryos enter the uterus at the late morula to early blastocyst stage 120-144h after ovulation (Oguri \& Tsutsumi, 1972; Betteridge et al., 1982; Boyle et al., 1989; Hinrichs \& Riera, 1990; Freeman et al., 1991). Oviductal transport may occur in mares when embryos have developed to a critical stage when they can initiate 
transport. The objective of this experiment was to test the hypothesis that horse embryos initiate oviductal transport in mares.

\section{Materials and Methods}

\section{Animals and treatments}

Day 6 uterine embryos were placed in the oviductal ampullae of day 2 or day 5 recipient mares (one embryo per recipient mare, $n=10$ mares). Initiated oviductal transport was estimated by the number of embryos that were recovered from the uterus $48 \mathrm{~h}$ after transfer (4 days after ovulation).

The experiment was conducted in July, 1990. Mares aged 3-15 years and weighing 300-500 kg were housed in a dry lot and fed approximately $7 \mathrm{~kg}$ of alfalfa hay and $1-2 \mathrm{~kg}$ of corn per day, as well as free-choice trace mineral salt mix. Stage of oestrous cycle and ovulation were detected by rectal palpation and transrectal ultrasonography (Ginther, 1986). Mares were estimated to be in oestrus when they had endometrial oedema and an ovarian follicle greater than $30 \mathrm{~mm}$ in diameter. Mares in oestrus were examined between 04:00 and 07:00 h daily to detect ovulation. Embryo donor and sham transfer mares in oestrus were artificially inseminated with pooled semen from three stallions every other day until ovulation was detected. The day of ovulation was defined as day 0 .

\section{Collection of uterine embryos}

Day 6 embryos were collected by transcervical uterine lavage (McKinnon et al., 1988). Embryos were immediately placed into a defined medium consisting of a 1:1 mixture of Ham's F-12 and Dulbecco's modified Eagle's medium (Sigma, St Louis, MO, USA) supplemented with insulin $\left(5 \mu \mathrm{g} \mathrm{ml}^{-1}\right)$, transferrin $\left(5 \mu \mathrm{g} \mathrm{ml}^{-1}\right)$, sodium selenite (5 $\mathrm{ng}$ $\left.\mathrm{ml}^{-1}\right)$, penicillin $\left(50 \mathrm{iu} \mathrm{ml}^{-1}\right)$ and streptomycin $\left(50 \mu \mathrm{g} \mathrm{ml}^{-1}\right)$.

\section{Embryo transfer}

Mares were premedicated with $0.04-0.08 \mathrm{mg}$ acepromazine $\mathrm{kg}^{-1}$ body weight. General anaesthesia was induced by intravenous infusion of $5 \%$ guaifenesin with $2 \mathrm{~g}$ sodium thiamylal $1^{-1}$ and maintained by inhalation of a halothaneoxygen mixture. The ovary and oviduct ipsilateral to ovulation were exposed through a flank laparotomy. Uterine embryos (one per mare) were surgically placed in the mid-ampullary region of the oviducts of the recipient mares (Peyrot et al., 1987). Medium alone was placed into the oviducts of inseminated sham-transfer mares.

\section{Statistical analysis}

The post-transfer proportions of uterine embryo collection were compared using Fisher's Exact Test. The diameters of pre-transfer and post-transfer embryos were compared using Student's $t$-test.

\section{Results}

Six of ten uterine embryos placed in the oviducts of day 2 recipient mares were transported to the uterus by day 4 . The number of embryos transported through the oviducts of the mares was not significantly less $(P>0 \cdot 1)$ for day 2 than for day 5 recipient mares $(6$ of 10 versus 9 of 10 , respectively; Table 1). The number of embryos transported through oviducts of mares was significantly greater $(P<0.05)$ for day 2 recipient mares than for sham transfer mares (6 of 10 versus 1 of 10 , respectively, Table 1).

There was no significant difference $(P>0 \cdot 1)$ in the pre-transfer diameter of embryos transferred to the oviducts of day 2 and day 5 recipient mares $(180 \pm 13.8 \mu \mathrm{m}$ versus $187 \pm 11.3 \mu \mathrm{m}$, respectively). The post-transfer diameter was significantly smaller $(P<0.05)$ for embryos collected from the uteri of day 2 than for day 5 recipient mares $(375 \pm 85.4 \mu \mathrm{m}$ versus $659 \pm 43.6 \mu \mathrm{m}$, respectively; Table 1). 
Table 1. Oviductal transport after surgical transfer of day 6 embryos into the mid-ampullary region of recipient mares

\begin{tabular}{lccc}
\hline & $\begin{array}{c}\text { Day } 5 \text { recipient } \\
\text { mares }\end{array}$ & $\begin{array}{c}\text { Day 2 recipient } \\
\text { mares }\end{array}$ & $\begin{array}{c}\text { Day 2 sham } \\
\text { transfer mares }\end{array}$ \\
\hline Number of mares & 10 & 10 & 10 \\
Oviductal transport* & $9 / 10^{\mathrm{a}}$ & $6 / 10^{\mathrm{a}}$ & $1 / 10^{\mathrm{b}}$ \\
$\begin{array}{l}\text { Embryo diameter } \dagger(\mu \mathrm{m}) \\
\quad \text { Before transfer } \\
\text { After transfer }\end{array}$ & $187 \pm 11 \cdot 3$ & $180 \pm 13 \cdot 8$ & - \\
\hline $\begin{array}{l}\text { * Recovery of embryos from uterus } 48 \mathrm{~h} \text { after transfer. } \\
\dagger \text { Mean } \pm \text { SEM. }\end{array}$ & & \\
$\begin{array}{l}\text { a.b } \\
\text { within rows }(P<0 \cdot 05) .\end{array}$
\end{tabular}

\section{Discussion}

The hypothesis that the horse embryo initiates oviductal transport was supported. Six of ten embryos placed in the oviducts of day 2 recipients were subsequently recovered from the uterus at day 4 , which is before the expected time of uterine entry at days 5-6. Oviductal transport in day 2 recipients was not significantly less than that found in day 5 recipients.

Oviductal transport did not appear to be initiated by the surgical transfer procedure, since oviductal transport occurred in only one sham transfer. A surgery-related inflammatory response may have initiated oviductal transport in this one mare.

Oviductal transport does not appear to be initiated by increased embryonic size since embryos do not increase in diameter before transport (Freeman et al., 1991). Oviductal transport does not appear to be initiated by a change in embryo surface morphology since the surface morphologies of oocytes and embryos are similar (Betteridge et al., 1976). In addition, embryos with markedly different surface morphologies (zona-enclosed compared to zona-free) initiated oviductal transport. The surface of embryos during normal oviductal transport is the zona pellucida (Betteridge et al., 1982). One embryo in this study and two embryos in a previous study (Freeman et al., 1989b) had shed their zonae pellucidae before they were placed in and transported through oviducts of recipient mares. The surface of these zona-free embryos during oviductal transport was the capsule (Betteridge et al., 1979).

It is suggested that horse embryos initiate oviductal transport by secreting a chemical. As horse embryos in the uterus initiate oviductal transport and uterine embryos develop in vitro (Freeman et al., 1989a), it would be logical to culture uterine embryos and identify embryonic secretory chemicals that potentially initiate oviductal transport.

Embryos increased in size at a slower rate after transfer to the oviduct of day 2 compared with day 5 recipient mares. The slower rate of growth may have been caused by asynchrony between embryos and recipient mares, as a decrease in embryonic growth rate occurs when cow and sheep uterine embryos are transferred to the uteri of less advanced recipients (Lawson et al., 1983; Albihn et al., 1991). Embryos were in oviducts of day 2 and day 5 recipient mares for undetermined times; the relative effect of oviductal or uterine environments could therefore not be evaluated.

The authors thank D. C. Kem, Twin Willows, D. W. Jacklin, T. Scheumann, D. Agnew and the Advisory Board of the Northwest Equine Reproduction Laboratory for support. The authors are grateful to D. Bingaman, T. Byrd, B. Hamilton, R. Haws, L. Lindsley, J. Lyon and L. Mitten for excellent technical assistance. Idaho Agricultural Experiment Station Publication Number 91A05. University of Idaho Research Council Seed Grant Number 681-Y112. 


\section{References}

Albihn, A., Gustafsson, H. \& Rodriguez-Martinez, H. (1991) Maternal influence on the early development of asynchronously transferred bovine embryos. Animal Reproduction Science 24, 25-35.

Betteridge, K.J., Eaglesome, M.D. \& Flood, P.F. (1979) Embryo transport through the mare's oviduct depends on cleavage and is independent of the ipsilateral corpus luteum. Journal of Reproduction and Fertility, Supplement 27, 387-394.

Betteridge, K.J., Eaglesome, M.D., Mitchell, D., Flood, P.F. \& Beriault, R. (1982) Development of horse embryos up to twenty-two days after ovulation: observations on fresh specimens. Journal of Anatomy 135, 191-209.

Betteridge, K.J., Flood, P.F. \& Mitchell, D. (1976) Possible role of the embryo in the control of oviductal transport in mares. In Ovum Transport and Fertility Regulation, pp. 381-389. Eds M. J. K. Harper, C. J. Pauerstein, C. E. Adams, E. M. Coutinho, H. B. Croxatto \& D. M. Paton. Scriptor, Copenhagen.

Betteridge, K.J. \& Mitchell, D. (1974) Direct evidence of retention of unfertilized ova in the oviduct of the mare. Journal of Reproduction and Fertility 39, 145-148.

Betteridge, K.J. \& Mitchell, D. (1975) A surgical technique applied to the study of tubal eggs in the mare. Journal of Reproduction and Fertility, Supplement 23, 519-524.

Boyle, M.S., Sanderson, M.W., Skidmore, J. \& Allen, W.R. (1989) Use of serial progesterone measurements to assess cycle length, time of ovulation and timing of uterine flushes in order to recover equine morulae. Equine Veterinary Journal, Supplement 8, 10-13.

Crisman, R.O., McDonald, L.E. \& Wallace, C.E. (1980) Oviduct (uterine tube) transport of ova in the cow. American Journal of Veterinary Research 41, 645-647.

David, J.S.E. (1975) A survey of eggs in the oviducts of mares. Journal of Reproduction and Fertility, Supplement 23, 513-517.

Flood, P.F., Jong, A. \& Betteridge, K.J. (1979) The location of eggs retained in the oviduct of mares. Journal of Reproduction and Fertility 57, 291-294.

Freeman, D.A., Butler, J.E., Weber, J.A., Geary, R.T. \& Woods, G.L. (1989a) Culture of equine embryos in complete media with oviductal tissue. Theriogenology 31, 194 (Abstract).

Freeman, D.A., Weber, J.A., Geary, R.T. \& Woods, G.L. (1991) Time of embryo transport through the mare's oviduct. Theriogenology 36, 823-830.

Freeman, D.A., Weber, J.A. \& Woods, G.L. (1989b) Transport of equine uterine embryos and rabbit embryos through the oviduct of the mare. Equine Veterinary Journal, Supplement 8, 86 (Abstract).

Ginther, O.J. (1986) Follicles (Chapter 10) and Uterus (Chapter 12). In Ultrasonic Imaging and Reproductive Events in the Mare, pp. 142-149, 174-187. Equiservices, Cross Plains, Wisconsin.

Hamilton, W.J. \& Laing, J.A. (1946) Development of the egg of the cow up to the stage of blastocyst formation. Journal of Anatomy 80, 194204.
Harper, M.J.K. (1988) Gamete and zygote transport. In The Physiology of Reproduction, pp. 103-134. Eds E. Knobil \& J. D. Neill. Raven Press, New York.

Hinrichs, K. \& Riera, F.L. (1990) Effect of administration of prostaglandin $\mathrm{F}_{2 a}$ on embryo recovery from the uterus on day 5 after ovulation in mares. American Journal of Veterinary Research 51, 451-453.

Holst, P.J. (1974) The time of entry of ova into the uterus of the ewe. Journal of Reproduction and Fertility 36, 427-428.

Lawson, R.A.S., Parr, R.A. \& Cahill, L.P. (1983) Evidence for maternal control of blastocyst growth after asynchronous transfer of embryos to the uterus of the ewe. Journal of Reproduction and Fertility 67, 477-483.

McKinnon, A.O., Squires, E.L., Voss, J.L. \& Cook, V.M. (1988) Equine embryo transfer. Compendium on Continuing Education for the Practicing Veterinarian 10, 343-355.

Mead, R.A., Joseph, M.M. \& Neirinckx, S. (1988) Optimal dose of human chorionic gonadotropin for inducing ovulation in the ferret. Zoo Biology 7 , 263-267.

Oguri, N. \& Tsutsumi, Y. (1972) Non-surgical recovery of equine eggs, and an attempt at non-surgical egg transfer in horses. Journal of Reproduction and Fertility 31, 187-195.

Onuma, H. \& Ohnami, Y. (1975) Retention of tubal eggs in mares. Journal of Reproduction and Fertility, Supplement 23, 507-511.

Ortiz, M.E., Bedregal, P., Carvajal, M.I. \& Croxatto, H.B. (1986) Fertilized and unfertilized ova are transported at different rates by the hamster oviduct. Biology of Reproduction 34, 777-781

Oxenreider, S.L. \& Day, B.N. (1965) Transport and cleavage of ova in swine. Journal of Animal Science 24, 413-417.

Peyrot, L.M., Little, T.V., Lowe, J.E., Weber, J.A. \& Woods, G.L. (1987) Autotransfer of Day 4 embryos from oviduct to oviduct versus oviduct to uterus in the mare. Theriogenology 28, 699-708.

Pomeroy, R.W. (1955) Ovulation and the passage of the ova through the fallopian tubes in the pig. Journal of Agricultural Science 45, 327-330.

Rasweiler, J.J. (1979) Differential transport of embryos and degenerating ova by the oviducts of the longtongued bat, Glossophaga soricina. Journal of Reproduction and Fertility 55, 329-334.

Steffenhagen, W.P., Pineda, M.H. \& Ginther, O.J. (1972) Retention of unfertilized ova in uterine tubes of mares. American Journal of Veterinary Research 33, 2391-2398.

Van Niekerk, C.H. \& Gerneke, W.H. (1966) Persistence and parthenogenetic cleavage of tubal ova in the mare. Onderstepoort Journal of Veterinary Research 31, 195-232.

Villalon, M., Ortiz, J.E., Aguayo, C. \& Munoz, J. (1982) Differential transport of fertilized and unfertilized ova in the rat. Biology of Reproduction 26, 337-341.

Wilson, J.M., Kreider, J.L. \& Potter, G.D. (1985) Nonsurgical recovery of degenerative ova from the uterus of mares. Theriogenology 23, 236 (Abstract).

Received 9 April 1991 